\title{
The Influence of the Curing Conditions on the Behavior of Jute Fibers Reinforced Concrete Cylinders
}

\author{
Yasmina Ed-Dariy ${ }^{1 *}$, Nouzha Lamdouar ${ }^{1}$, Toufik Cherrad ${ }^{1}$, Ancuta Rotaru² , Marinela Barbuta ${ }^{2}$, \\ Petru Mihai ${ }^{3}$ \\ ${ }^{1}$ Department of Civil Engeneering, Mohammadia School of Engineers, Mohammed V University of Rabat, Avenue Ibn Sina B.P. 765 \\ Agdal, Rabat, Morocco \\ 2 Department of Transportation Infrastructure and Foundations, Gheorge Asachi Technical University of lasi, Faculty of Civil Engineering \\ and Building Services, Bulevardul Profesor Dr. doc. Dimitrie Mangeron 43, Iasi 700050, Romania \\ ${ }^{3}$ Department of Concrete Structures, Building Materials, Technology and Management, Gheorge Asachi Technical University of lasi, \\ Faculty of Civil Engineering and Building Services, Bulevardul Profesor Dr. doc. Dimitrie Mangeron 43, Iasi 700050, Romania \\ * Corresponding author, e-mail: yasminaeddariy@research.emi.ac.ma
}

Received: 10 April 2021, Accepted: 04 July 2020, Published online: 28 July 2020

\begin{abstract}
This paper presents an innovative method of reinforcement of concrete based on the use of the Jute fibers composites. These renewable raw bioresource fibers are available at a low cost. Moreover, they can be compared to Glass Fiber-Reinforced Polymer (GFRP) by enhancing the resistance of Jute Fiber-Reinforced Polymer (JFRP), while improving the compatibility between the fiber and the resin. For that purpose, this paper presents an experimental study that evaluates the influence of the curing conditions (time and temperature) on the behavior of JFRP laminates and concrete members strengthened by JFRP. The curing conditions at $30{ }^{\circ} \mathrm{C}$ for $2 \mathrm{~h} 30 \mathrm{~min}$ and at $50{ }^{\circ} \mathrm{C}$ for $1 \mathrm{~h}$ were the only two parameters studied and determined on the basis of Sikadur 330 properties and preliminary tests. Through the experimental tests, the maximum load capacity and observed failure modes are investigated. The results indicated that the curing at $30^{\circ} \mathrm{C}$ for $2 \mathrm{~h} 30 \mathrm{~min}$ is the optimum curing condition. In addition, a low difference in the maximum load capacity was noted in the case of $50^{\circ} \mathrm{C}$. As to the failure modes, all the specimens cured with additional heat before being left under room conditions, have shown the ductile mode failure, especially in the case of specimens cured at $30^{\circ} \mathrm{C}$ during $2 \mathrm{~h} 30 \mathrm{~min}$. The analytical model conducted in this paper predicts the elastic modulus depending on temperature. The obtained results and proposed model can be used as input parameters in the analysis and design of externally strengthened members with Jute FRP composites.
\end{abstract} Keywords

JFRP composites, epoxy resin, reinforcement, curing conditions, concrete

\section{Introduction}

The effectiveness of reinforcement of concrete by the synthetic Fiber-Reinforced Polymer (FRP) was approved by several experimental studies [1, 2]. However, these kinds of fibers still have many drawbacks, including high energy consumption during the manufacturing process. Moreover, they are not eco-friendly [3]. This is why strengthening existing structures involves the development of new materials based on natural components [4].

Jute and Flax are one of the most widely used biodegradable fibers in the composite industry. Thanks to their low density and cost. They used as structural strengthening systems for different reinforced concrete $(\mathrm{RC})$ elements such as columns, beams, and slabs $[5,6]$. As stated by
Hussain and Ali [7], the Jute fibers enhance crack resistance and toughness of concrete. According to Tan et al. [8], the ultimate load of concrete columns has been increased by wrapping with JFRP composites. Alam and Al Riyami [9] showed that the toughness and strength of beams have been improved by the reinforcement using the natural fibers $[10,11]$. On the other hand, the maximum load capacity, ductility, and energy absorption have been increased by using the flax fiber-reinforced polymers (FFRP) [12].

While the success of this technique depends, to a large extent, on the charge transfer in the concrete-fiber interface [13-15]. Furthermore, the polymerization conditions affect directly the performance of bonded joints [16] and 
more especially the time and temperature which are essential and necessary parameters to trigger the polymerization of epoxy resin and which is frequently underestimated [17]. Since an ambient curing cycle does not achieve the desired performance, many experimental studies have shown that stiffness and strength properties of the concrete increase rapidly due to high curing temperatures. Similar observations confirmed that the minimum curing duration needed for reaching the maximum shear strain was clearly related to the curing temperature [18]. The research conducted by Lapique and Redford [19] has shown that the necessary curing time to reach the maximum tensile strength can be significantly reduced from several hours at room temperature to approximately $30 \mathrm{~min}$ at $90{ }^{\circ} \mathrm{C}$. Furthermore, a faster strength evolution was observed at higher temperatures, as the same mechanical properties obtained at $23{ }^{\circ} \mathrm{C}$ after 28 days could be attained at $64{ }^{\circ} \mathrm{C}$ after only $4 \mathrm{~h}$ [20]. Dodiuk and Kenig [21] have observed that the strength achieved after $1 \mathrm{~h}$ cured at $60{ }^{\circ} \mathrm{C}$ was higher than that obtained after 10-20 days of curing at room temperature. Therefore, it turns out that it is necessary to optimize the time and the temperature; the parameters which can improve the mechanical properties of the composite material, and which could lead to an improvement of the behavior of the reinforced element. And since the effect of curing conditions on the behavior of concrete confined by JFRP composites has never been studied before, so it was necessary to study the behavior of the JFRP composite first and then the JFRP reinforced concrete members. The first section of this paper presents the materials used and the methodology followed. The second section resumes the results obtained from the tensile and compression test in terms of maximum load capacity and failure modes. In the third section, an analytical modeling part was conducted for predicting the elastic modulus in the function of the temperature ranging from $20^{\circ} \mathrm{C}$ to $50^{\circ} \mathrm{C}$.

\section{Experimental program}

\subsection{Materials}

The used Jute fibers are from Textila Company, Iasi, Romania and the resin used is an epoxy Sikadur 330 delivered by Sika Company from Romania. Table 1 resumes the properties of the Sikadur 330 epoxy resin.

\subsection{Preparation of Jute laminates}

To characterize the mechanical properties of the composite, the Jute fibers fabric were cut to the dimensions of $25 \mathrm{~mm} \times 250 \mathrm{~mm}$ in accordance with ASTM D 3039 [22] (Fig. 1(a)).

The preparation of the composite was performed manually using the wet lay-up process. Each specimen was prepared by applying a layer of epoxy, followed by the Jute fibers fabric and then covered by another layer of epoxy as shown in Fig. 1(a). In order to maintain the nominal dimensions of the specimens, the resin excess was removed by cutting the ends using a universal cutting machine equipped with a diamond disc. All laminates have $1 \mathrm{~mm}$ of thickness. The reference specimens were polymerized at room temperature $\left(20{ }^{\circ} \mathrm{C}\right)$. For the specimens whose processes of curing are accelerated and after 1 hour of their preparation; the first group are placed in the oven for $2 \mathrm{~h}$ 30 min under $30^{\circ} \mathrm{C}$ and for the second group are polymerized for 1 hour at $50{ }^{\circ} \mathrm{C}$. After that, both of them are left at room temperature for 7 days before being tested.

\subsection{Preparation of tabs}

Tabs increase the total area to which the load applied at both ends, reducing stresses at the end of specimens. Besides, the geometry, tab material, and adhesive must be well selected to minimize stress concentrations near the end of tabs. According to ASTM D 3039 [22], the material used for laminate tabs is sandpaper with a geometry of $25 \times 50 \mathrm{~mm}$ (Fig. 1).

\subsection{Preparation of concrete-JFRP specimens}

In the system of reinforcement of the concrete by using the FRP composite, the transition zone is more important when the total porosity of the substrate is higher [23]. Consequently, the concrete surface was prepared to remove the impurities, increase the rate of the pores on the surface, and facilitate the penetration of the resin inside the concrete in order to make a strong bond between the concrete and the composite. The procedure of strengthening the concrete started with concrete surface preparation manually utilizing sandpaper, which led to an increase in surface roughness. Cleaning the lateral surface from dust with high pressure of the air was the second step. Before the application

Table 1 Properties of the Sika-dur 330 epoxy resin

\begin{tabular}{|c|c|c|c|c|c|c|}
\hline Resin & $\begin{array}{l}\text { Density of the mix } \\
D\left(\mathrm{~kg} / \mathrm{dm}^{3}\right)\end{array}$ & $\begin{array}{c}\text { Compressive } \\
\text { strength } f_{c, a}[\mathrm{MPa}]\end{array}$ & $\begin{array}{l}\text { Tensile strength } f_{c, a} \\
{[\mathrm{MPa}]}\end{array}$ & $\begin{array}{c}\text { Modulus of } \\
\text { elasticity } E[\mathrm{GPa}]\end{array}$ & $\begin{array}{l}\text { Transient glass } \\
\text { temperature }\end{array}$ & $\begin{array}{c}\text { Elongation at break } \\
\varepsilon u[\%]\end{array}$ \\
\hline Sikadur 330 & 1.3 & $30\left(7\right.$ days $\left.+23^{\circ} \mathrm{C}\right)$ & $33.8\left(7\right.$ days $\left.+23{ }^{\circ} \mathrm{C}\right)$ & $4.5\left(7\right.$ days $\left.+23{ }^{\circ} \mathrm{C}\right)$ & $58^{\circ} \mathrm{C}$ & 0.9 \\
\hline
\end{tabular}




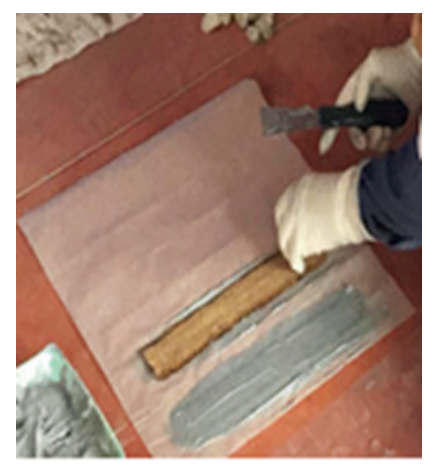

(a)

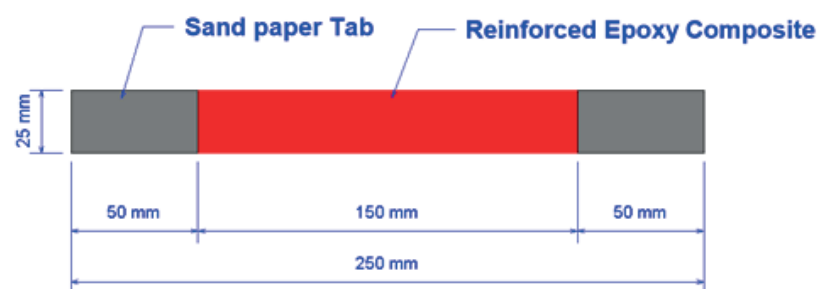

(c)

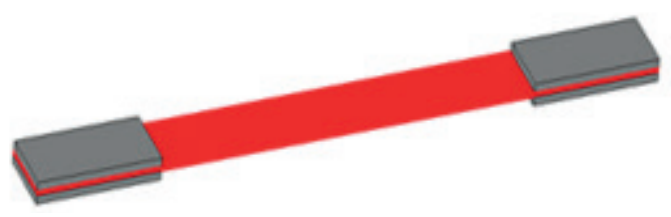

(d)

Fig. 1 Details of Jute FRP coupon specimens for tensile testing; (a) Jute composite, (b) JFRP composites coupon specimens, (c) Top view,

(d) Side view

of strengthening material, a layer of adhesive was applied firstly to the lateral surface and followed by the Jute fibers fabric, and then covered by another layer of epoxy. And to ensure a good bond between the concrete-JFRP and to avoid any entrapped air bubbles at the epoxy/fabric or epoxy/concrete interface, the Jute fibers fabrics were applied with constant pressure with a roller. The adhesive Sikadur 330 used is a bi-component adhesive, consisting of a resin and a hardener agent with a mixing ratio of $4: 1$. The components were mixed in a clean and transparent container for $3 \mathrm{~min}$ at circular speeds of 400-600 RPM.

\subsection{Curing step}

This study tested 18 cylindrical specimens of $100 \mathrm{~mm}$ diameter and $200 \mathrm{~mm}$ high, including 3 unconfined and 15 JFRP-confined cylinders specimens which are divided into 5 groups. The first group of concrete-JFRP members which designed as reference specimens are left at room temperature $\left(20^{\circ} \mathrm{C}\right)$ for 7 days before being tested. For the specimens whose curing process is accelerated, were left under ambient conditions for an hour after the application of the strengthening system (Fig. 2(a)) and before being placed in the oven. Those specimens are divided into four groups (as summarized in Table 2). Specimens which cured at $30^{\circ} \mathrm{C}$ for $2 \mathrm{~h} 30 \mathrm{~min}$ were left at room temperature for 3 days. Specimens cured at $30^{\circ} \mathrm{C}$ for $2 \mathrm{~h} 30 \mathrm{~min}$, then kept for 7 days at room temperature. Specimens cured at $50{ }^{\circ} \mathrm{C}$ for $1 \mathrm{~h}$ and left at room temperature for 3 days. Specimens cured at $50{ }^{\circ} \mathrm{C}$ for $1 \mathrm{~h}$ and kept at room temperature for 7 days. The oven used in this experimental part is a universal MEMMERT 100-800 oven (Fig. 2(b)) that has a maximum temperature of $200{ }^{\circ} \mathrm{C}$. The temperature inside the oven was controlled by using a digital system as shown in (Fig. 2(c)).

\subsection{Mechanical testing}

\subsubsection{Tensile test}

In order to characterize the mechanical properties of the Jute-FRP composite, the laminates were tested by applying a uniaxial load across both ends of the specimens,

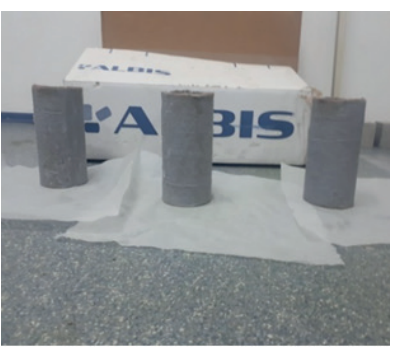

(a)

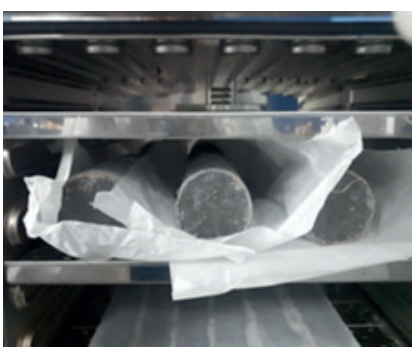

(b)

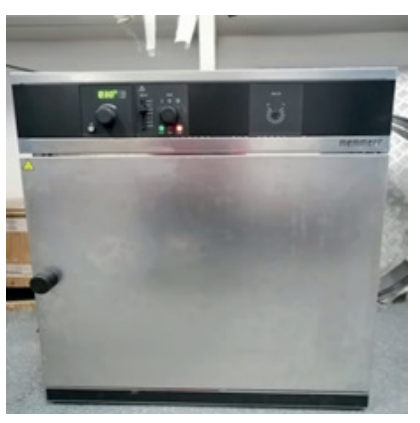

(c)

Fig. 2 (a) Specimens before accelerated curing process, (b) Specimens placed in the oven, (c) Oven used

Table 2 Curing conditions specimens

\begin{tabular}{lc}
\hline Group & Details \\
\hline 1st group & 20 degree C, 7 days \\
2snd group & 30 degree C, 2 h 30 min for 3 days \\
3rd group & 30 degree C, 2 h 30 min for 7 days \\
4th group & 50 degree C, 1 h for 3 days \\
5th group & 50 degree C, 1 h for 7 days \\
\hline
\end{tabular}


using suitable jaws of attachment to the WAW-600 E universal testing machine. Both ends of the laminates are fitted with tabs. The tensile test was carried out in the composite materials laboratory in Iasi which all specimens are prepared and tested according to ASTM D3039 [22] guidelines. Laminates are pulled in tension at a rate of $2 \mathrm{~mm} / \mathrm{min}$. The load-displacement of each specimen is recorded using data acquisition Maxtest software which is connected to the lower and upper load cells.

\subsubsection{Compression test}

All the specimens cured at room temperature, $30^{\circ} \mathrm{C}$ or $50^{\circ} \mathrm{C}$, and tested after 3 or 7 days come under compression testing using the Universal Testing Machine WAW-600 E with $4 \mathrm{KN} / \mathrm{s}$ applied loading speed (Fig. 3). All the specimens are prepared and tested following the NF EN 12390-3 [24] standard. On other hand, in the aim to avoid eccentricity generation during axial load application, two circular discs laid on both sides of the concrete specimens, one on the upside and the second one on the bottom. The results are obtained using the data acquisition system Maxtest software.

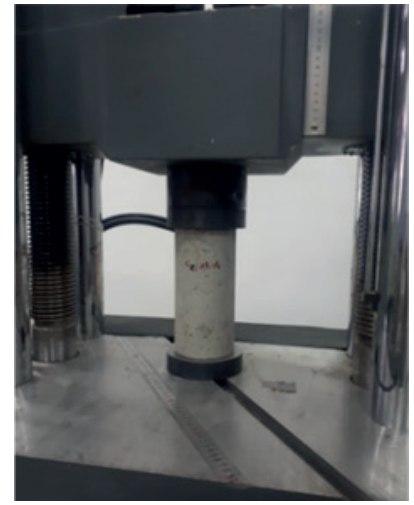

(a)

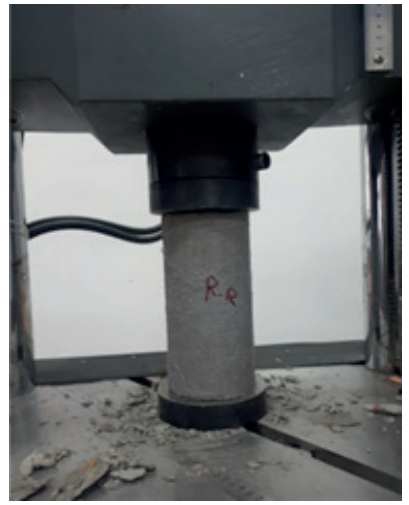

(b)

\section{Results and discussions}

\subsection{Failure Mode of JFRP Laminates}

The straight fracture was observed perpendicular to the axial stress direction (as shown in Fig. 4), and the failure occurred in a brittle manner. The ruptures produced in areas far from the extremities of laminates, which explain the advantages of using tabs that reduce stresses in the composite at the end of specimens. All laminates cured at room temperature, $30^{\circ} \mathrm{C}$ or $50^{\circ} \mathrm{C}$ displayed failure modes per ASTM D 3039 [22] (Paragraph 11.9) which are lateral failures and can be referred to as an L.G.M (Lateral Gage middle) failures (Fig. 4). Changing the temperature from $30{ }^{\circ} \mathrm{C}$ to $50{ }^{\circ} \mathrm{C}$, the failure modes have appeared the same as observed at room temperature $\left(20^{\circ} \mathrm{C}\right)$.

\subsection{Interpretation of Load-Displacement behavior of JFRP Laminates}

The laminates have been evaluated parallel to the axis of application of the tensile force. All the curves obtained have linear elastic behavior until breakage. The maximum load capacity was $1.33 \mathrm{KN}$, corresponding to a $3.85 \mathrm{~mm}$

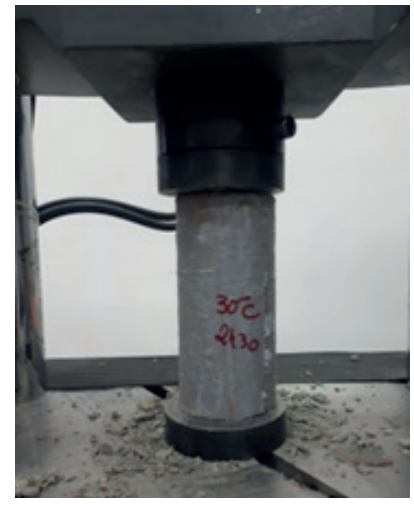

(c)

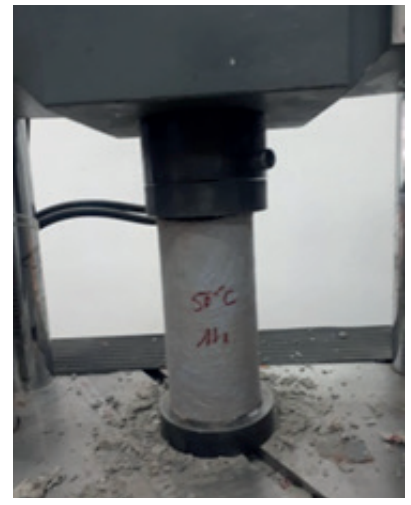

(d)

Fig. 3 (a) Unreinforced specimens, (b) Reinforced specimens, (c) Specimens cured at $30^{\circ} \mathrm{C}$ for $2 \mathrm{~h} 30$, (d) Specimens cured at $50{ }^{\circ} \mathrm{C}$ for $1 \mathrm{~h}$

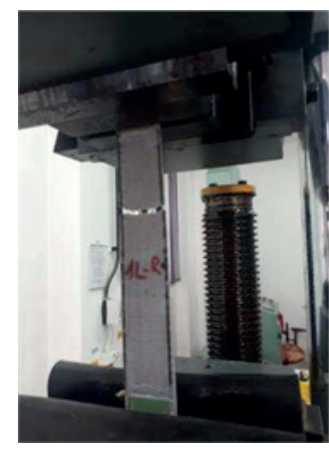

(a)

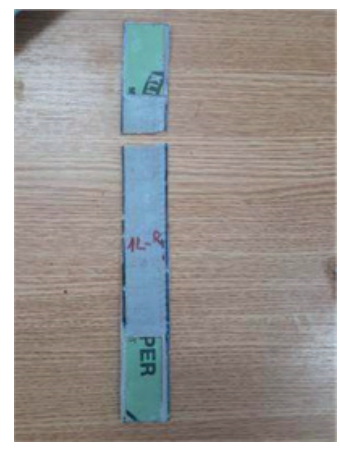

(b)

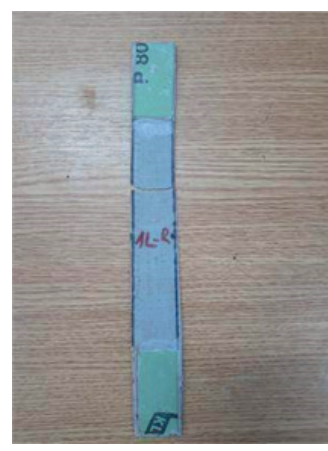

(c)

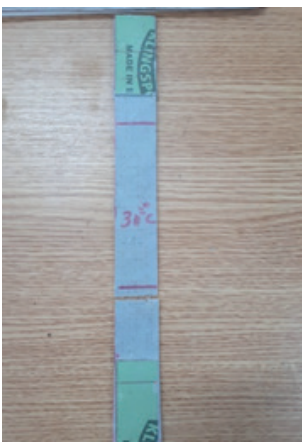

(d)

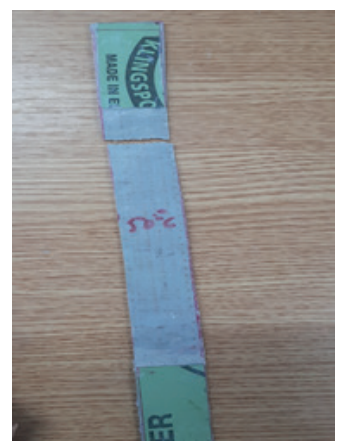

(e)

Fig. 4 Failure modes of JFRP laminates; (a) JFRP laminate during the tensile test, (b) Failure mode of JFRP lamniate cured under room temperature (1), (c) Failure mode of JFRP lamniate cured under room temperature (2), (d) Failure mode of JFRP lamniate cured under $30{ }^{\circ} \mathrm{C}$ for $2 \mathrm{~h} 30 \mathrm{~min}$,

(e) Failure mode of JFRP lamniate cured under $50{ }^{\circ} \mathrm{C}$ for $1 \mathrm{~h}$ 
displacement for specimens cured at $30^{\circ} \mathrm{C}$ for $2 \mathrm{~h} 30 \mathrm{~min}$ and tested after 7 days. And 1.14KN for specimens cured at $50{ }^{\circ} \mathrm{C}$ and tested after 7 days. The less value was noted in the case of specimens cured at room temperature with $0.9 \mathrm{KN}$ and $2.6 \mathrm{~mm}$ of displacement (Fig. 5).

By analyzing the achieved results, it can be concluded that increasing the temperature from 20 to $30{ }^{\circ} \mathrm{C}$ (just for $2 \mathrm{~h} 30 \mathrm{~min}$ ) allows increasing the maximum load by $47 \%$. And increasing the curing temperature from $20{ }^{\circ} \mathrm{C}$ to $50{ }^{\circ} \mathrm{C}$ just forlh allows increasing the load value by $26.7 \%$. This shows the positive effect of accelerating the curing process while relying on additional heat. As far as the curing time is concerned, $2 \mathrm{~h} 30 \mathrm{~min}$ for the case of $30^{\circ} \mathrm{C}$ was more than enough to reach a superior value of maximum load capacity as compared to specimens cured at the ambient conditions ( 7 days under $20^{\circ} \mathrm{C}$ ). Contrary, in the case of $1 \mathrm{~h}$ for the $50{ }^{\circ} \mathrm{C}$, it was perhaps necessary to increase the curing acceleration time by a few more minutes.

\subsection{Mechanical properties of JFRP-Laminates}

Following the Eqs. (1), (2), and (3) the mechanical properties are summarized in Table 3.

Ultimate tensile strength [MPa]:

$\sigma=\frac{F}{S}$.

Elongation at failure [\%]:

$\varepsilon=100 \times \frac{\Delta l}{l}$.

Elasticity modulus at failure [GP]:

$E=\frac{\sigma}{\varepsilon}$.

As shown in Table 3, the maximum values of tensile strength have been increased in the case of $30{ }^{\circ} \mathrm{C}$ and $50{ }^{\circ} \mathrm{C}$, compared to laminates cured at room temperature

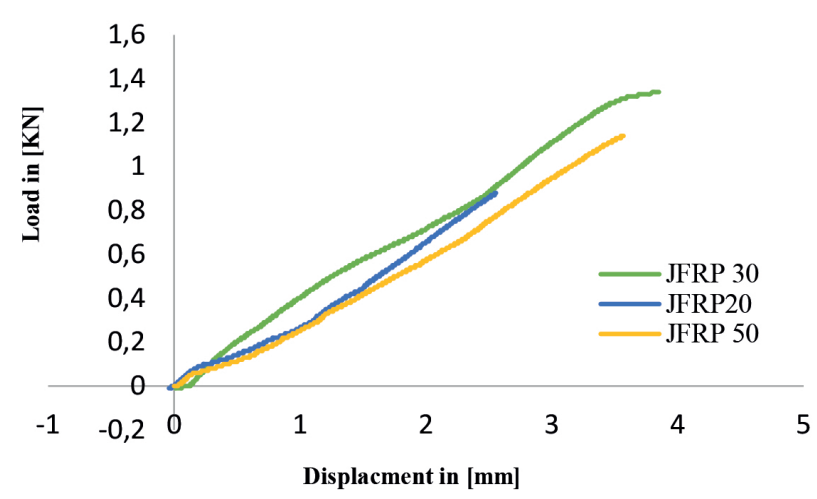

Fig. 5 Load-Displacement curves of laminates cured at room temperature $20^{\circ} \mathrm{C}$, at $30^{\circ} \mathrm{C}$ for $2 \mathrm{~h} 30 \mathrm{~min}$ and at $50^{\circ} \mathrm{C}$ for $1 \mathrm{~h}$ (specimens cured at $20^{\circ} \mathrm{C}$ ). This increase was also noted by Mhanna et al. [25] who explained that the mechanical properties of epoxy improve at higher temperatures below $\mathrm{Tg}$ due to increased production of crosslinkages which led to the rapid initiate chemical reactions.

On the other hand, the laminates hardened at $50{ }^{\circ} \mathrm{C}$ were noted a less value of elasticity modulus compared to specimens cured at $30{ }^{\circ} \mathrm{C}$.

\subsection{Interpretation of load-displacement behavior of concrete JFRP-composites}

Analyzing the load-displacement curves as shown in Fig. 6, Fig. 7 and Table 4, all specimens have a non-linear behavior up to failure. Specimens cured at $30^{\circ} \mathrm{C}$ and crushed after 3 or 7 days as well as those cured at $50^{\circ} \mathrm{C}$ and crushed after 7 days, have noted the maximum compressive force with maximum displacement. For specimens cured at $30{ }^{\circ} \mathrm{C}$ for $2 \mathrm{~h} 30 \mathrm{~min}$ and crushed after 3 or 7 days, showed similar behavior and similar maximum load capacity with a low difference of the displacement value.

Ambient cured specimens (C-JFRP-R) have shown a lower displacement and load capacity than the specimens cured at $30{ }^{\circ} \mathrm{C}$ crushed after 3 or 7 days (C-JFRP-30-3, C-JFRP-30-7) and those cured at $50{ }^{\circ} \mathrm{C}$ and disrupted after 3 days or 7 days (C-JFRP-50-3, C-JFRP-50-7).

Table 3 Properties of the JFRP laminate

\begin{tabular}{lccc}
\hline & Cured at $20{ }^{\circ} \mathrm{C}$ & Cured at $30{ }^{\circ} \mathrm{C}$ & Cured at $50{ }^{\circ} \mathrm{C}$ \\
\hline $\begin{array}{l}\text { Ultimate tensile } \\
\text { strength [MPa] }\end{array}$ & 36 & 53.2 & 45.6 \\
$\begin{array}{l}\text { Elasticity modulus } \\
\text { at failure [GPa] }\end{array}$ & 3.46 & 3.45 & 3.28 \\
$\begin{array}{l}\text { Elongation } \\
\text { at failure [\%] }\end{array}$ & 1.04 & 1.54 & 1.39 \\
\hline
\end{tabular}

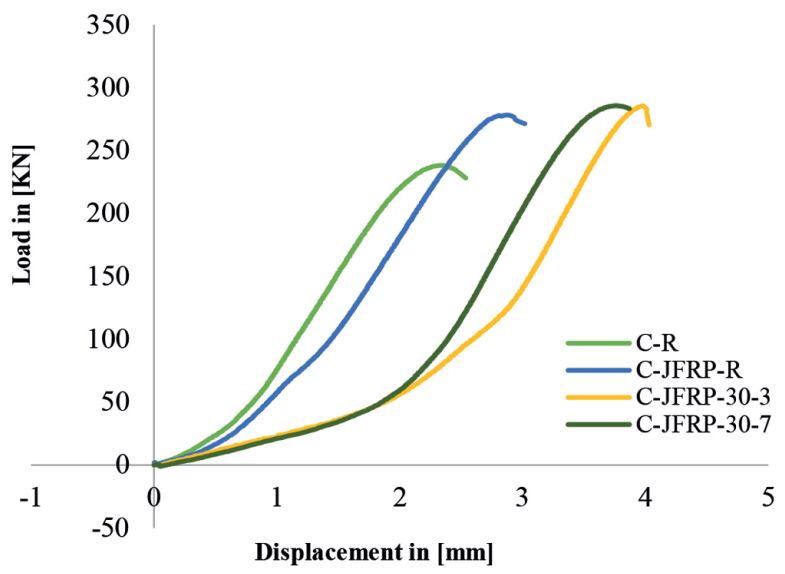

Fig. 6 Load-displacement curves of compressive tests on unreinforced and reinforced concrete cylinders 


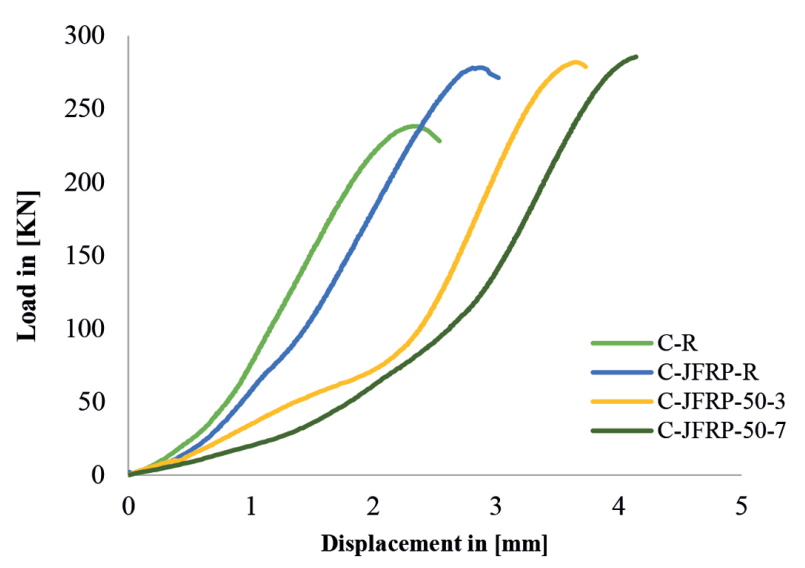

Fig. 7 Load-displacement curves of compressive tests on unreinforced and reinforced concrete cylinders

Table 4 Specimen details, average maximum load and displacement

\begin{tabular}{|c|c|c|c|}
\hline Code & Signification & $\begin{array}{c}\text { Average } \\
\text { maximumm } \\
\text { load capacity } \\
{[\mathrm{KN}]}\end{array}$ & $\begin{array}{c}\text { Displacement } \\
{[\mathrm{mm}]}\end{array}$ \\
\hline C-R & $\begin{array}{l}\text { Plain concrete } \\
\text { (reference) }\end{array}$ & 238.2 & 2.356 \\
\hline C-JFRP-R & $\begin{array}{l}\text { JFRP reinforced } \\
\text { concrete cured at } \\
\text { room temperature }\end{array}$ & 278.2 & 2.88 \\
\hline C-JFRP-30-3 & $\begin{array}{l}\text { JFRP reinforced } \\
\text { concrete cured } \\
\text { at } 30^{\circ} \mathrm{C} \text { during } 2 \mathrm{~h} \\
30 \text { and tested after } \\
3 \text { days }\end{array}$ & 285.6 & 4.07 \\
\hline C-JFRP-30-7 & $\begin{array}{l}\text { JFRP reinforced } \\
\text { concrete cured } \\
\text { at } 30{ }^{\circ} \mathrm{C} \text { during } 2 \mathrm{~h} \\
30 \text { and tested after } \\
7 \text { days }\end{array}$ & 285.8 & 3.76 \\
\hline C-JFRP-50-3 & $\begin{array}{l}\text { JFRP reinforced } \\
\text { concrete cured at } \\
50^{\circ} \mathrm{C} \text { during } 1 \mathrm{~h} \text { and } \\
\text { tested after } 3 \text { days }\end{array}$ & 282 & 3.649 \\
\hline C-JFRP-50-7 & $\begin{array}{l}\text { JFRP reinforced } \\
\text { concrete cured at } 50 \\
{ }^{\circ} \mathrm{C} \text { during } 1 \mathrm{~h} \text { and } \\
\text { tested after } 7 \text { days }\end{array}$ & 285.6 & 4.12 \\
\hline
\end{tabular}

On the other hand, the specimens cured at $50{ }^{\circ} \mathrm{C}$ and crushed after 3 days (C-JFRP-50-3) exhibited similar behavior to specimens cured at room temperature (C-JFRP-R) with a small variation in maximum load.

\subsection{Interpretation of maximum load capacity of concrete JFRP-composites}

As shown in Fig. 8, reinforcing the concrete members with the Jute fibers fabric increased the maximum load capacity by $16.8 \%$ compared to unreinforced specimens. The case

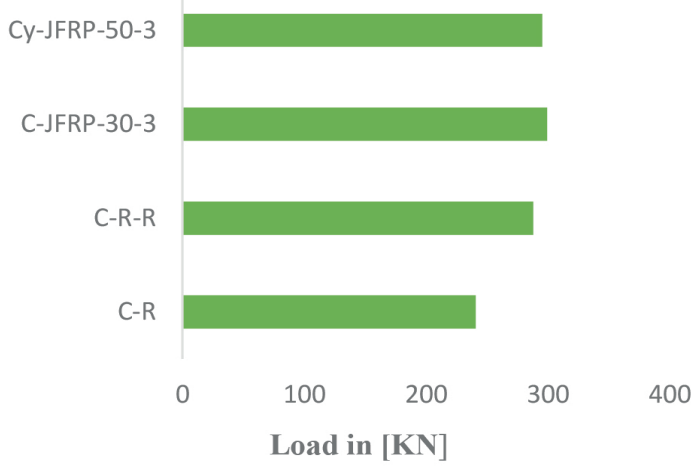

(a)

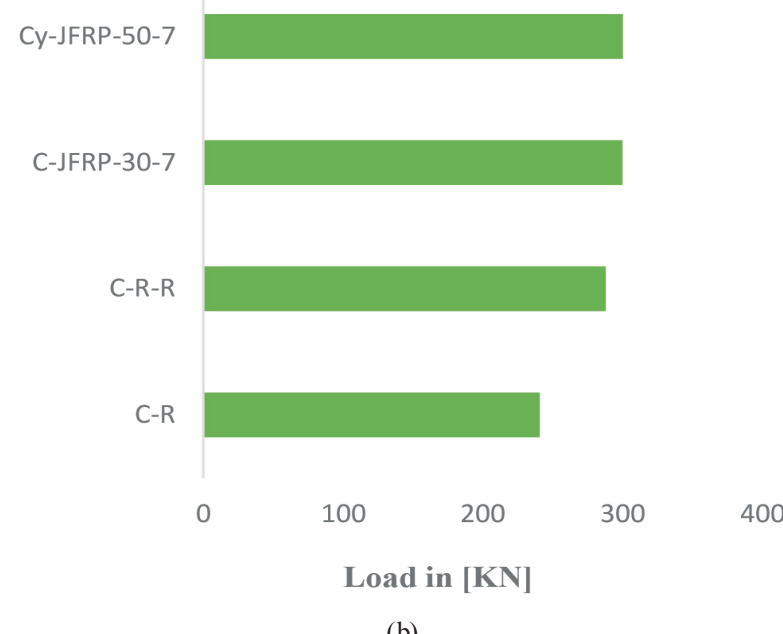

(b)

Fig. 8 Comparison of average maximum load capacity; (a) Specimens tested after 3 days of the curing process, (b) Specimens tested after 7 days of the curing process

of specimens cured under $30{ }^{\circ} \mathrm{C}$ for $2 \mathrm{~h} 30 \mathrm{~min}$ and crushed after 3 days, displayed a $19.9 \%$ of increase in the maximum load capacity compared to unreinforced samples and $2.66 \%$ compared to reinforced specimens cured under room temperature. Specimens cured under $30{ }^{\circ} \mathrm{C}$ for $2 \mathrm{~h}$ $30 \mathrm{~min}$ and crushed after 7 days showed an increase of $2.8 \%$ and $20 \%$ compared to reinforced specimens cured under room temperature and unreinforced members, respectively. Moreover, after 3 days of curing, the crushing of the reinforced members, cured at $50{ }^{\circ} \mathrm{C}$ for 1 hour showed an increase in the breaking load of $1.37 \%$ compared to reinforced specimens (cured under room temperature) and $18.39 \%$ compared to unreinforced specimens. The members crushed after 7 days displayed an increase of $2.66 \%$ and $19.9 \%$ compared to reinforced patterns cured at room temperature and unreinforced specimens, severally.

Following the results obtained, all specimens cured with additional heat $\left(30^{\circ} \mathrm{C}\right.$ for $2 \mathrm{~h} 30 \mathrm{~min}$ and $50{ }^{\circ} \mathrm{C}$ for $1 \mathrm{~h}$ ) showed a higher load capacity compared to specimens 
cured at room temperature. Czaderski et al. [26] confirmed that all samples exsiccated for 30 minutes at $90{ }^{\circ} \mathrm{C}$ (whether tested minutes after the heating process or after 2 days) fail at higher forces than those for reference specimens cured at room temperature. The study conducted by Al-Tamimi et al. [18] confirmed the improvement of bonds in CFRP systems when exposed to an elevated temperature due to polymer crosslinking and the creation of complex interactions. On the other hand, the results obtained from the tensile test demonstrate that adhesion between fiber and matrix is improved which can explain more the improvement of the behavior of concrete reinforced by JFRP composites.

Besides, it turns out a very low difference variation in the maximum load capacity in the case of specimens cured below $30^{\circ} \mathrm{C}$ (crushed either after 3 days or after 7 hardening days), and specimens cured below $50{ }^{\circ} \mathrm{C}$ and crushed after 7 curing days. The fact that the specimens reached the maximum resistance only after 3 days of curing which is the same resistance found in the case of the specimens crushed after 7 days, confirms that $2 \mathrm{~h} 30$ min with $30{ }^{\circ} \mathrm{C}$ of temperature were the optimal conditions that led to a correct crosslinking.

On contrary, the least value of the ultimate load was noted in the case of specimens cured at $50{ }^{\circ} \mathrm{C}$ for $1 \mathrm{~h}$ and crushed after 3 days; this means that these conditions were not enough to reach an important crosslinking. Furthermore, the results show that increasing the temperature from $30^{\circ} \mathrm{C}$ to $50^{\circ} \mathrm{C}$ did not improve the maximum load capacity.

On the other hand, increasing of the curing time gave values almost similar to those found in specimens cured at $30{ }^{\circ} \mathrm{C}$ for $2 \mathrm{~h} 30 \mathrm{~min}$ and crushed after 3 days.

As a conclusion, the observed improvement confirms that the curing process of some adhesive systems at room temperature involves additional heat to raise the temperature of specimens above the glass transition temperature $(T g)$. By heating the specimens above the $T g$ value, reactive groups become mobile again, and the curing can reach high levels of crosslinking. The extent of the curing reaction influences the final structure of the adhesive network, which changes the overall properties of the cured epoxy network [27]. The crosslinking density depends on the processing conditions and especially on the polymerization temperature. Hence, each reaction site becomes a crosslinking node; the compactness of nodes will condition the internal cohesion of the joint. A dense network shows reduced molecular mobility of chains and high rigidity. On the other hand, a low crosslinking density leads to a loose matrix, in which chains slide relative to each other. The network cohesion will be weak and the joint will poorly transmit the forces between the two assembled parts.

\subsection{Failure modes of concrete cylinders reinforced with JFRP-composites}

The following figures present the failure modes of all unconfined (Fig. 9) and confined cylinder specimens (Fig. 10-12). All the specimens cured with additional heat

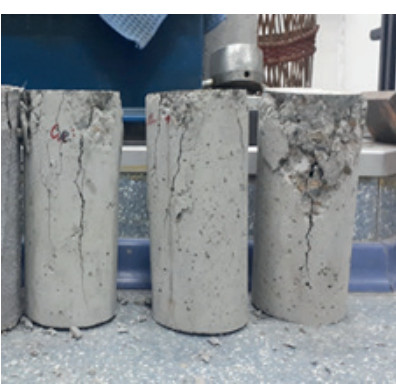

(a)

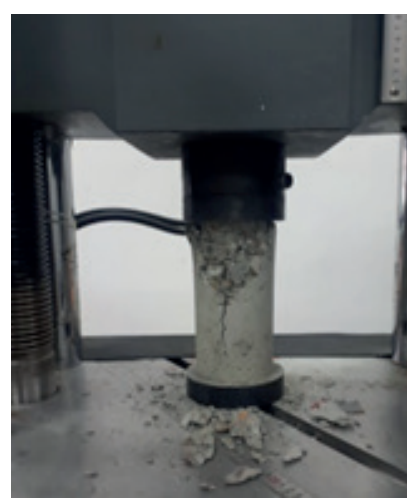

(b)
Fig. 9 Unconfined cylinders specimens; (a) Specimens after the test, (b) Specimens during the compression test
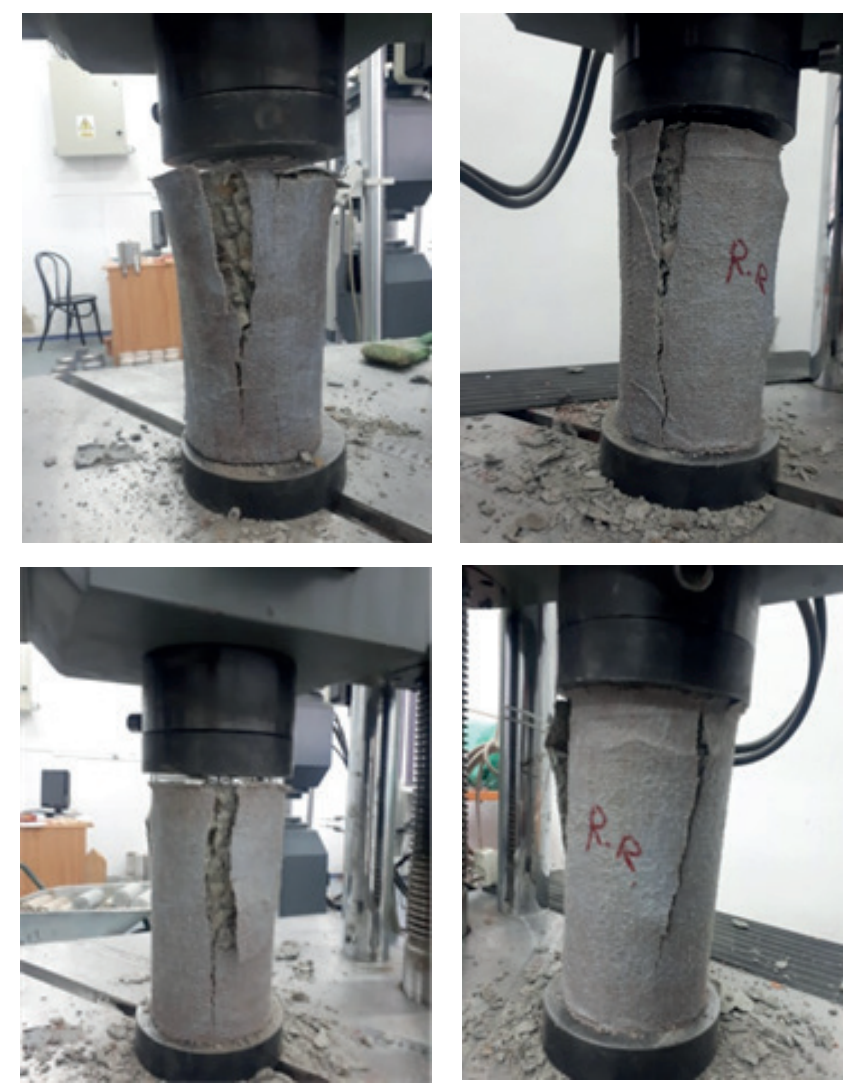

Fig. 10 Confined cylinder specimens cured at room temperature 

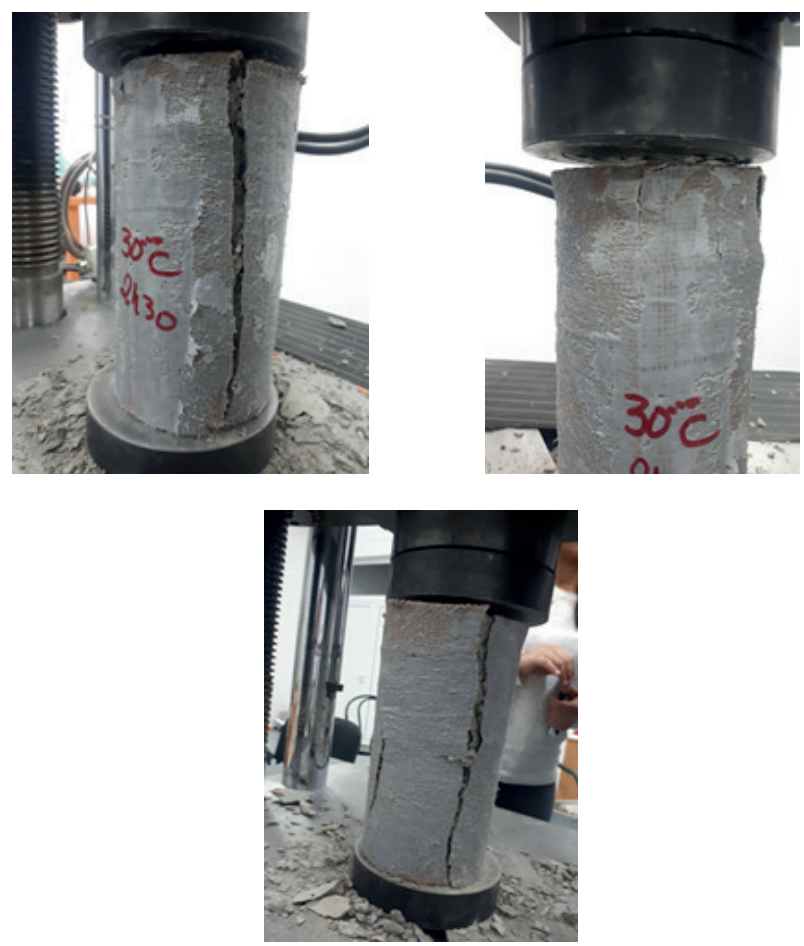

Fig. 11 Confined cylinder specimens cured at $30{ }^{\circ} \mathrm{C}$ for $2 \mathrm{~h} 30$
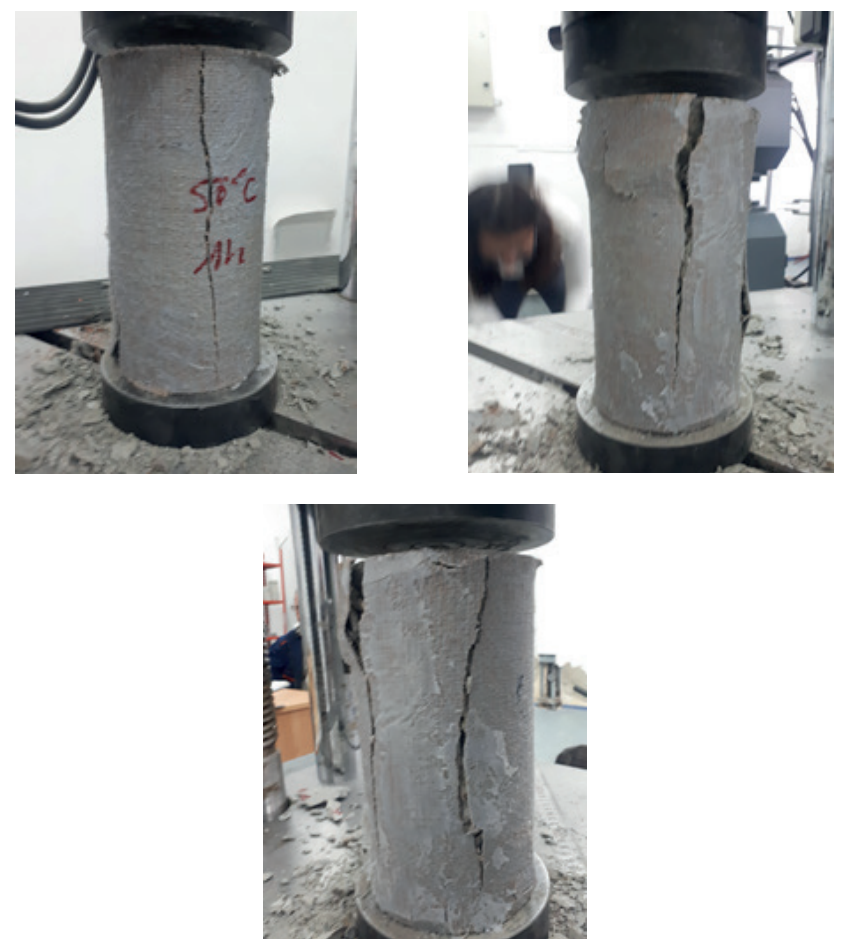

Fig. 12 Confined cylinder specimens cured at $50{ }^{\circ} \mathrm{C}$ for $1 \mathrm{~h}$

before being left under ambient conditions have shown a ductile mode failure, especially in the case of specimens cured at $30{ }^{\circ} \mathrm{C}$ for $2 \mathrm{~h} 30 \mathrm{~min}$. It was observed two longitudinal ruptures and one other discontinuous rupture from the bottom of the specimens to the middle with the apparition of some cracks from the top (Fig. 11). This kind of rupture where the rupture in the FRP laminate originates from the top surface and continues throughout the bottom in a single line is called continuous laminate rupture.

The specimens cured at $50{ }^{\circ} \mathrm{C}$ showed more than three longitudinal failures, which explains that the strength of the adhesive layer had not developed as a whole during this duration and under this temperature (Fig. 12).

On the other hand, the specimens cured under room temperature have shown a high number of cracks with continuous and discontinuous longitudinal rupture.

In conclusion, the difference noticed was in the number of cracks that appeared on the specimens. More precisely, in the case of the unreinforced specimens, a very high number of cracks were observed. Generally, they are concentrated at the upper part with the appearance of other cracks spread along the length of the specimens. On the other hand, in the case of the concrete-JFRP specimens, the difference was also noticed at the level of the detachment of the composite from the concrete, this mode of failure was very remarkable only in the case of specimens that were cured under ambient conditions. This detachment explains that the bond created between the JFRP and concrete was not strong enough (Fig. 10).

\section{Modeling of Elastic Moduls of JFRP laminates cured at elevated temperature}

As indicated previously, increasing the curing temperature enhanced the strength of the JFRP laminates. On the other hand, the elastic modulus has noted a decrease of $5.48 \%$ in the case of $50{ }^{\circ} \mathrm{C}$ compared to specimens of reference. Using existing analytical models that simulate the modulus of elasticity of FRP materials as a function of temperature, this study predicts the experimental results.

In the literature, the general model proposed by Gibson et al. [28] as indicated in Eq. (4) predicted the variation of the Elastic Modulus of FRP materials in terms of temperature:

$P(T)=R^{n}\left[\frac{P_{u}+P_{R}}{2}-\frac{P_{u}-P_{R}}{2}\left\{\tanh \left(k_{m}\left(T-T^{\prime}\right)\right\}\right]\right.$,

with:

$P(T)$ is the elastic modulus at a specified temperature $T, P_{u}$ and $P_{R}$ which represents the elastic modulus of the material at room temperature and the relaxed modulus of the material, respectively. $k_{m}$ and $T^{\prime}$ are variables determined by fitting the experimental data of the laminate. All those coefficients based on a regression analysis. $R^{n}$ is a power law factor based on the residual resin content. 
The use of composite materials based on carbon fibers, basalt or a combination of carbon and basalt or polyethylene terephthalate generates different behaviors, which give rise to new models to predict the mechanical properties as in terms of temperature variation, including those of Mhanna et al. [25], Hawileh et al. [29], and Yu and Kodur [30]. In the study initiated by the group of Mhana et al. [25], the PET-FRP laminates have displayed a nonlinear behavior that opposes the linear response of the CFRP and BFRP materials used by Hawileh et al. [29], Yu and Kodur [30].

This work focuses on a comparison of the experimental results with the following models developed to predict the modulus of elasticity based on Gisbon's equation.

Mhanna et al. [25] have developed three models because the stress-strain response has exhibited a nonlinear behavior which led to dividing curves into three phases with three moduli $\left(E_{1}, E_{2}\right.$ and $\left.E_{3}\right)$ :

$$
\begin{aligned}
& E_{1}(T)=0.57-0.425 \tanh [(0.032(T-76.52))], \\
& E_{2}(T)=0.572-0.428 \tanh [(0.024(T-69.65))], \\
& E_{3}(T)=0.727-0.273 \tanh [(0.018(T-72.43))] .
\end{aligned}
$$

Hawileh's et al. models [29]:

The following models predict the elastic modulus of carbon (C), basalt (B) and carbon-basalt (BC) at elevated temperatures:

$$
\begin{aligned}
& E_{c}(T)=0.55-0.455 \tanh [(0.014(T-60.27))], \\
& E_{B}(T)=0.86-0.140 \tanh [(0.035(T-163.24))], \\
& E_{B C}(T)=0.705-0.295 \tanh [(0.091(T-196.34))] .
\end{aligned}
$$

$\mathrm{Yu}$ and Kodur [30] predicted the elastic modulus of CFRP strip:

$$
E(T)=0.51-0.49 \tanh [(0.0035(T-340))] .
$$

And proposed for CFRP bars the following model:

$$
E(T)=0.51-0.49 \tanh [(0.0033(T-320))] \text {. }
$$

\subsection{Comparison of experimental results with analytical models}

Fig. 13 compares experimental data to predicted results using published models in the literature. As shown in Fig. 13, the model (1) (Eq. (5)) of Mhanna et al. [25] gave results close to the experimental results. On the other

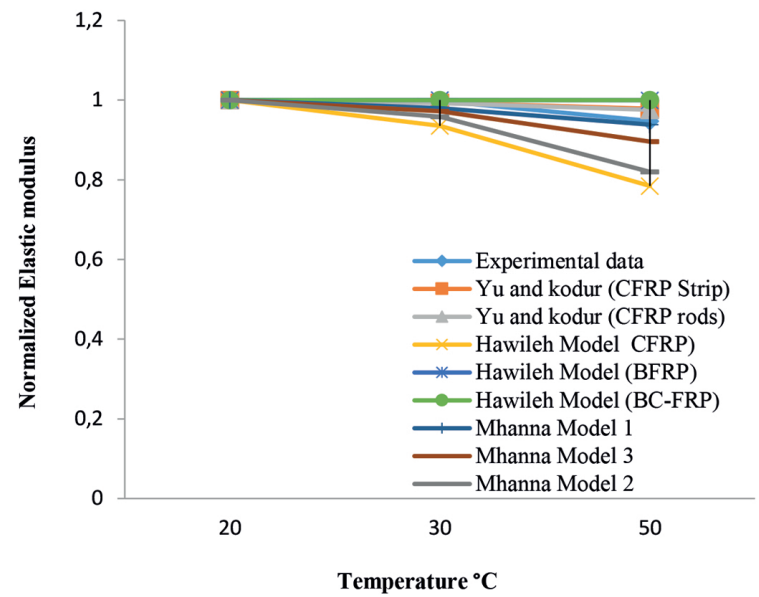

Fig. 13 Comparison between experimental data and predicted results using published models in the literature

hand, the second model (Eq. (6)) and third model (Eq. (7)) of Mhanna et al. [25] as well as the models of Hawileh et al. [29], Yu and Kodur [30], did not predict the experimental results. For the two curves given by the $\mathrm{Yu}$ and Kodur [30] models, whether for the case of CFRP or CFRP strips, rods divide into two parts. For the fraction between 20-30 ${ }^{\circ} \mathrm{C}$, the values displayed are lower than the experimental values. On the other hand, from $30-50{ }^{\circ} \mathrm{C}$, the fractions are higher than the experimental results. The same in the case of both models of Hawileh et al. [29] (BFRP) and (BC-FRP) Eq. (9) and Eq.(10), gave higher values compared to experimental results. The model of Hawileh et al. [29] (CFRP) Eq. (8) gave lower fractions compared to the probing values. The three models of Mhanna et al. [25], showed lower amounts compared to the probing values. The difference in fractions in the case of Hawileh et al. [29] resides in the difference between the types of materials in use, precisely in the case of basalt-based composites or the combination of basalt and carbon. The difference noted in the case of Yu and Kodur [30] can be explained by the use of CFRP rods or strips whose behavior and capacity differ in a complementary way compared to the same JFRP parameters. The work of Mhanna et al. [25] and Hawileh et al. [29] concluded that, for models based on strips and rods conducted on Near Surface Mounted (NSM), strips and rebars cannot predict the results of laminates prepared by wet lay-up. This conclusion applies to model (2) (Eq (6)), and model (3) (Eq. (7)) of Mhanna et al. [25] as well. On the other hand, a small difference appeared in the case of the model (1) of Mhanna et al. [25] (Eq. (5)), explained by the fact that this model only represents the first part of the response, which gave values close to the experimental values. 


\subsection{Proposed model}

To find a model that predicts the experimental results, a square regression analysis performed to obtain the coefficients $\left(\mathrm{km}, \mathrm{T}^{\prime}\right)$ based on Gibson et al. [28] equation. To achieve a minimum square error between the experimental data and the empirical model, a Microsoft Excel "solver" function was used. Table 4 resumes the calculated coefficients of the elastic modulus for the JFRP laminates.

This paper proposes the following model Eq. (13) for predicting the elastic modulus of JFRP at elevated temperatures:

$$
E(T)=0.880-0.546 \tanh [(0.082(T-65.90)] .
$$

As a result and from Fig. 14 that shows a comparison between experimental and predicted results, it is clear that a close correlation exists between predicted and measured results of modulus of elasticity of JFRP laminates in terms of variation of curing temperature.

As shown in Table 5, the predicted elastic modulus values using the model developed in this study had a small Mean Absolute Percent Error (MAPE) of $0.02 \%$, and the correlation coefficient (R) equal to 0.999985 .

In general, if the correlation $(\mathrm{R})$ is between $0.2-0.5$, a moderately weak correlation applies. If it is between 0.8 and 1.0, a strong relationship applies. If it is between 0.5 and 0.8 , a slight correlation applies.

The results show clearly the close correlation between predicted and experimental results. So, the developed model can be used to predict the elastic modulus of JFRP Laminates at elevated temperatures. It can be used as input parameters in computer simulation to evaluate the behavior of concrete strengthened by the JFRP.

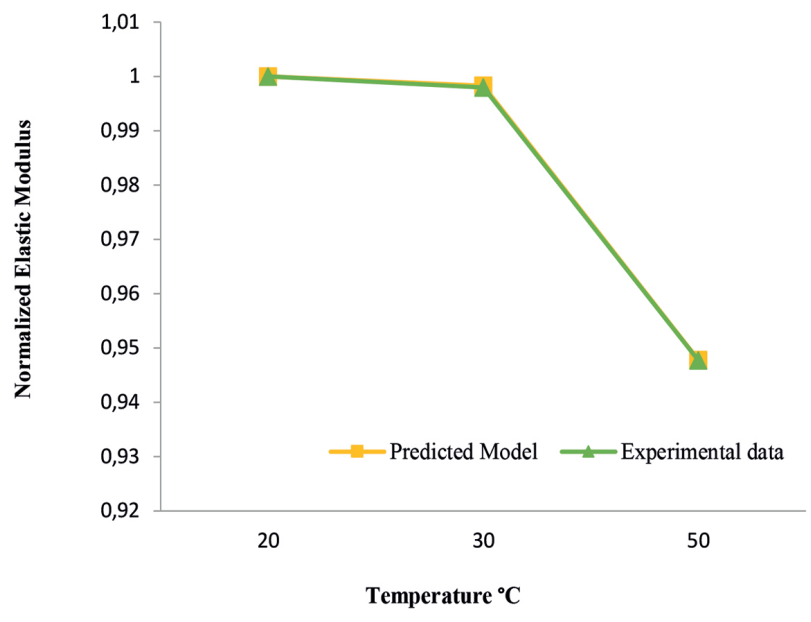

Fig. 14 Comparison of measured and predicted elastic modulus results for JFRP laminates using the proposed model

\section{Conclusions}

Results of this investigation reveal the following observations and conclusions:

1. The reinforcement of concrete elements with Jute fiber fabrics increased the maximum load capacity by $19.6 \%$ compared to unreinforced specimens.

2. In the case of elements cured at $30{ }^{\circ} \mathrm{C}$ for $2 \mathrm{~h} 30 \mathrm{~min}$ and crushed after 3 days, an increase in the maximum breaking load of $24.4 \%$ was noted compared to unreinforced specimens. And 4\% was noted compared to reinforced specimens cured at room temperature.

3. The results have shown in the case of elements cured under $30{ }^{\circ} \mathrm{C}$ for $2 \mathrm{~h} 30 \mathrm{~min}$ and crushed after 7 days, an increase of $4.14 \%$ compared to reinforced specimens cured at room temperature and $20.6 \%$ compared to unreinforced elements.

4. The reinforced of concrete elements by JFRP cured at $50{ }^{\circ} \mathrm{C}$ during 1 hour and left for 3 days of curing (under room conditions) have shown an increase in the breaking load of $2.54 \%$ and $22.6 \%$ compared to reinforced specimens and unreinforced specimens, severally.

5. In the case of reinforced elements cured under $50{ }^{\circ} \mathrm{C}$ for 1 hour and left for 7 days under ambient conditions, an increase was noted of $4.3 \%$ compared to reinforced specimens cured at room temperature and $24.7 \%$ compared to unreinforced specimens.

6. All the specimens cured with additional heat before being left under ambient conditions have shown the ductile mode of failure, clearly, observed in the case of specimens cured at $30^{\circ} \mathrm{C}$ and $50{ }^{\circ} \mathrm{C}$.

7. A very high number of cracks was noted in the case of the unreinforced specimens. On the other hand, in the case of reference concrete members reinforced by JFRP (cured under ambient conditions), a detachment of the composite from the concrete was observed. Which demonstrated that the bond created between the JFRP and concrete was not strong enough.

Table 5 Derived coefficients based on Gisbon et al model [28] for elastic modulus of JFRP laminates

\begin{tabular}{lc}
\hline Coefficient & Laminate JFRP \\
\hline$P_{u}$ & 1 \\
$P_{R}$ & 0.76 \\
$K_{m}$ & 0.082 \\
$T^{\prime}$ & 65.90 \\
MAPE $(\%)$ & 0.02 \\
$R$ & 0.99985 \\
\hline
\end{tabular}


8. The adhesion between the fiber and matrix is improved, which led to an improvement of the behavior of concrete reinforced by JFRP composite. All the results obtained from the tensile test were used to further demonstrate the contribution of curing conditions on the behavior of concrete confined by JFRP composites.

9. The developed model can be used to predict the elastic modulus of the JFRP Laminates at elevated temperature and as input parameters in computer simulation to evaluate the behavior of concrete strengthened by JFRP.

\section{References}

[1] Salama, A. S. D., Hawileh, R. A., Abdalla, J. A. "Performance of externally strengthened RC beams with side-bonded CFRP sheets", Composite Structures, 212, pp. 281-290, 2019.

https://doi.org/10.1016/j.compstruct.2019.01.045

[2] Hawileh, R. A., Nawaz,W., Abdalla, J. A., Saqan, E. I. "Effect of flexural CFRP sheets on shear resistance of reinforced concrete beams", Composite Structures, 122, pp. 468-476, 2015.

https://doi.org/10.1016/j.compstruct.2014.12.010

[3] Gholampour, A., Ozbakkaloglu, T. "A review of natural fiber composites: properties, modification and processing techniques, characterization, applications", Journal of Materials Science, 55, pp. 829-892, 2020.

https://doi.org/10.1007/s10853-019-03990-y

[4] Ed-Dariy,Y., Lamdour, N., Cherradi, T., Rotaru, A., Barbuta, M., Mihai, P., Judele, L. "The Behavior of Concrete Cylinders Confined by JFRP Composites: Effect of $\mathrm{KOH}$ Solution", presented at 5th World Congress Civil structural and Environment Engineering, Virtual Confernce, October, 2020.

https://doi.org/10.11159/icsect20.163

[5] Burrola-Núñez, H., Herrera-Franco, P. J., Rodríguez-Félix, D. E., Soto-Valdez, H., Madera-Santana, T. J. "Surface modification and performance of jute fibers as reinforcement on polymer matrix: an overview", Journal of Natural Fibers, 16, pp. 944-60, 2018. https://doi.org/10.1080/15440478.2018.1441093

[6] Ed-Dariy, Y., Lamdouar, N., Cherradi, T., Rotaru, A., Barbuta, M., Mihai, P., Judele, L. "Experimental Investigation of the Effects of Naoh and $\mathrm{KOH}$ Solution on the Behavior of Concrete Square Columns Reinforced by JFRP Composites", presented at 5th World Congress Civil structural and Environment Engineering, Virtual Confernce, October, 2020.

https://doi.org/10.11159/icsect20.167

[7] Hussain, T., Ali, M. "Improving the impact resistance and dynamic properties of jute fiber reinforced concrete for rebars design by considering tension zone of FRC", Construction and Building Materials, 213, pp. 592-607, 2019.

https://doi.org/10.1016/j.conbuildmat.2019.04.036

[8] Tan, H., Yan, L., Huang, L., Wang, Y., Li, H., Chen, J. "Behavior of sisal fiber concrete cylinders externally wrapped with jute FRP", Polymer Composites, 38, pp. 1910-1917, 2015.

https://doi.org/10.1002/pc.23761

\section{Acknowledgement}

The authors would like to acknowledge the great support of Sika Company and also, to show our gratitude to all the persons who worked with us to fulfill this paper, especially to Mr. Marinescu and Mr. Poenaru from the Faculty of Civil Engineering and Building Services from « Gheorghe Asachi » Technical University of Iasi, Romania.

[9] Alam, M. A., Al Riyami, K. "Shear strengthening of reinforced concrete beam using natural fibre reinforced polymer laminates", Construction and Building Materials, 162, pp. 683-696, 2018. https://doi.org/10.1016/j.conbuildmat.2017.12.011

[10] Chen, C., Yang, Y., Yu, J., Yu, J., Tan, H., Sui, L., Zhou, Y. "Ecofriendly and mechanically reliable alternative to synthetic FRP in externally bonded strengthening of RC beams: Natural FRP", Composite Structures, 241, Article number: 112081, 2020. https://doi.org/10.1016/j.compstruct.2020.112081

[11] Zhang, T., Yin, Y., Gong, Y., Wang, L. "Mechanical properties of jute fiber $\square$ reinforced high $\square$ strength concrete", Structural Concrete, 21(2), pp. 703-712, 2020.

https://doi.org/10.1002/suco.201900012

[12] Chakraborty, S., Kundu, S. P., Roy, A., Basak, R. K., Adhikari, B., Majumder, S. B. "Improvement of the mechanical properties of jute fibre reinforced cement mortar: A statistical approach", Construction and Building Materials, 38, pp. 776-784, 2013.

https://doi.org/10.1016/j.conbuildmat.2012.09.067

[13] Huang, L., Yan, B., Yan, L., Xu, Q., Tan, H., Kasal, B. "Reinforced concrete beams strengthened with externally bonded natural flax FRP plates", Composites Part B: Engineering, 91, pp. 569-578, 2016. https://doi.org/10.1016/j.compositesb.2016.02.014

[14] Yan, L. "Plain concrete cylinders and beams externally strengthened with natural flax fabric reinforced epoxy composites", Materials and Structures, 49, pp. 2083-2095, 2016. https://doi.org/10.1617/s11527-015-0635-1

[15] Ed-Dariy, Y., Lamdour, N., Cherradi, T., Rotaru, A., Barbuta, M., Mihai, P. "Effect of alkali treatment of Jute fibers on the compressive strength of normal-strength concrete members strengthened with JFRP composites", Journal of Applied Science and Engineering, 23, pp. $677-685,2020$ https://doi.org/10.6180/jase.202012_23(4).0012

[16] Naser, M., Hawileh, R., Abdalla, J. A., Al-Tamimi, A. "Bond Behavior of CFRP Cured Laminates: Experimental and Numerical Investigation", Journal of Engineering Materails and Technology, 134, Article number: 021002, 2012. https://doi.org/10.1115/1.4003565 
[17] Hallonet, A. "Développement et caractérisation d'un matériau composite à base de fibres de lin: application au renforcement de structures en béton par collage externe" (Development and characterization of a composite material based on flax fibers: application to the reinforcement of concrete structures by external bonding), Doctoral dissertation, Université de Lyon, 2016. (in French)

[18] Al-Tamimi, A. K., Hawileh, R. A., Abdalla, J. A., Rasheed, H. A., Al-Mahaidi, R. "Durability of the Bond between CFRP Plates and Concrete Exposed to Harsh Environments", Journal of Materials in Civil Engineering, 27(9), Article number: 04014252, 2015. https://doi.org/10.1061/(ASCE)MT.1943-5533.0001226

[19] Lapique, F., Redford, K. "Curing effects on viscosity and mechanical properties of a commercial epoxy resin adhesive", International Journal of Adhesion and Adhesives, 22(4), pp. 337-346, 2002. https://doi.org/10.1016/S0143-7496(02)00013-1

[20] Matsui, K. "Effects of curing conditions and test temperatures on the strength of adhesive-bonded joints", International Journal of Adhesion and Adhesives, 1084), pp. 277-284, 1990. https://doi.org/10.1016/0143-7496(90)90046-Z

[21] Dodiuk, H., Kenig, S. "Low temperature curing epoxies for structural repair", Progress in Polymer Science, 19(3), pp. 439-467, 1994. https://doi.org/10.1016/0079-6700(94)90002-7

[22] ASTM "ASTM D3039 / D3039M-17 Standard Test Method for Tensile Properties of Polymer Matrix Composite Materials", ASTM International, West Conshohocken, PA, USA, 2017. https://doi.org/10.1520/D3039_D3039M-17

[23] Toutanji, H., Ortiz, G. "The effect of surface preparation on the bond interface between FRP sheets and concrete members", Composite Structures, 53(4), pp. 457-462, 2001. https://doi.org/10.1016/S0263-8223(01)00057-5

[24] European Standards "EN 12390-3B Testing hardened concrete Part3: Compressive strength of test specimens", British Standards Institution, London, UK, 2009.
[25] Mhanna, H. H., Hawileh, R. A., Abuzaid, W., Naser, M. Z., Abdalla, J. A. "Experimental Investigation and Modeling of the Thermal Effect on the Mechanical Properties of Polyethylene-Terephthalate FRP Laminates", Journal of Materials in Civil Engineering, 32(10), Article number: 04020296, 2020. https://doi.org/10.1061/(ASCE)MT.1943-5533.0003389

[26] Czaderski, C., Martinelli, E., Michels, J., Motavalli, M. "Effect of curing conditions on strength development in an epoxy resin for structural strengthening", Composites Part B: Engineering, 43(2), pp. 398-410, 2012. https://doi.org/10.1016/j.compositesb.2011.07.006

[27] $\mathrm{Wu}, \mathrm{C}$.-S. "Influence of post-curing and temperature effects on bulk density, glass transition and stress-strain behaviour of imidazole-cured epoxy network", Journal of Materials Science, 27, pp. 2952-2959, 1992. https://doi.org/10.1007/BF01154105

[28] Gibson, A. G., Wu, Y.-S., Evans, J. T., Mouritz, A. P. "Laminate Theory Analysis of Composites under Load in Fire", Journal of Composite Materials, 40(7), pp. 639-658, 2006. https://doi.org/10.1177\%2F0021998305055543

[29] Hawileh, R. A., Abdalla, J. A., Hasan, S. S., Ziyada, M. B., AbuObeidah, A. "Models for predicting elastic modulus and tensile strength of carbon, basalt and hybrid carbon-basalt FRP laminates at elevated temperatures", Construction and Building Materials, 114, pp. 364-373, 2016. https://doi.org/10.1016/j.conbuildmat.2016.03.175

[30] Yu, B., Kodur, V. "Effect of temperature on strength and stiffness properties of near-surface mounted FRP reinforcement", Composites Part B: Engineering, 58, pp. 510-517, 2014. https://doi.org/10.1016/j.compositesb.2013.10.055 